\title{
ANALISIS DETERMINAN PENDAPATAN USAHA INDUSTRI MIKRO KECIL TAHU DI TRUNAN,TIDAR SELATAN,MAGELANG SELATAN KOTA MAGELANG
}

\author{
Wahyu Bagas Setiaji ${ }^{1}$, Rifki Khoirudin ${ }^{2}$ \\ Universitas Ahmad Dahlan \\ wahyubagas23031995@gmail.com
}

\begin{abstract}
This study aims to analyze the influence of whether business capital, the number of workers, work experience and working hours affect the income of small micro-tofu industries in Trunan, Tidar Selatan Sub-district, South Magelang District, Magelang City. The research data was obtained from the questionnaire (primary) and several observations and direct interviews with the parties concerned. The findings of the study indicate that the independent variables consisting of business capital, the number of workers and work experience have a positive and significant effect. With these results, it is expected that entrepreneurs to increase production and income of small micro industries know that it needs to be supported by the support of various factors of production such as capital, the number of skilled workers and work experience. Because business experience also affects the income of entrepreneurs who know for themselves. In addition, the longer the businessman runs his business, the products produced by these entrepreneurs will be increasingly recognized by consumers and the distributors know who will become customers of course.
\end{abstract}

Keywords: industry of tofu, Venture capital, number of employees, work experience, working hours.

JEL Classification: $(2 \mathrm{~K}, 1 \mathrm{H})$

\section{PENDAHULUAN}

Indonesia merupakan salah satu negara yang masuk dalam kategori negara berkembang. Proses transformasi struktural di Indonesia berlangsung dengan sangat cepat. Perubahan seperti ini banyak terjadi di semua negara berkembang termasuk Indonesia. Daerah-daerah di Indonesia mulai mengembangkan sektor industri, sehingga memperkecil kesenjangan dengan sektor pertanian. Proses industrialisasi dan pembangunan industri sebenarnya merupakan salah satu jalur untuk meningkatkan kesejahteraan masyarakat dalam arti tingkat hidup yang lebih maju maupun taraf hidup yang lebih baik (Arsyad, 2010:353).

Hal tersebut akhirnya berdampak pada pertumbuhan usaha-usaha milik maysrakat atau UMKN yang ada di Indonesia tanpa terkecuali di Kota Magelang. Di Kota Megelang sangatlah wajar apabila industri milik masyarakat mulai berkembang, dikarenakan wilayah dari Kota Magelang ini tidaklah terlalu luas dan sektor pertanian atau sektor lainnya belum bisa diandalkan untuk menopang perekonomian di Kota ini. 
Kondisi perekonomian Kota Magelang dapat tercermin melalui struktur PDRB Kota Magelang. Dalam struktur PDRB dapat dilihat andil tiap sektor terhadap pertumbuhan ekonomi Kota Magelang. Struktur PDRB Kota Magelang di dominasi 4 sektor yaitu sektor Industri Pengolahan, sektor Konstruksi, sektor Perdagangan, dan sektor Administrasi Pemerintahan. Menurut data dari BPS Kota Magelang sumbangan PDRB sektor industri pengolahan sebesar 1.128.331, sektor konstruksi sebesar 1.167.173, sektor perdagangan sebesar 1.006.283, dan sektor administrasi pemerintahan sebesar 842.640 pada tahun 2016 . Hal itu berarti Sektor industri pengolahan dapat dikatakan menjadi salah satu penopang utama perekonomian Kota Magelang , Karena dari data PDRB yang ada di Kota Magelang setiap tahun mengalami peningkatan. Misalnya, pada tahun 2012 sebesar 746.653 tahun 2013 sebesar 812.115 tahun 2014 sebesar 934.259 tahun 2015 sebesar 1.043 .860 dan di tahun 2016 sebesar 1.128.331. (BPS Magelang Dalam Angka 2012-2016)

Dengan kondisi tersebut sektor industri menjadi salah satu sektor ekonomi yang mampu menyerap tenaga kerja dan pendapatan ekonomi masyarakat Kota Magelang. Berdasarkan data dari dinas perindustrian dan perdagangan Kota Magelang, data tenaga kerja yang bekerja pada sektor industri dalam rekap data umkm kota Magelang yaitu sebanyak 13.804 jiwa pada tahun 2017. Sedangkan jumlah tenaga kerja paling banyak terdapat di kecamatan Magelang Selatan dengan jumlah tenaga kerja 6012. Selain itu meskipun jumlah pelaku usaha lebih sedikit dibandingkan dengan kecamatan Magelang Tengah, akan tetapi jumlah omset kecamatan Magelang Selatan yang berjumlah 33.694.893.500 jauh lebih besar dari kecamatan Magelang Tengah sebesar 18,313.719.000. begitupun juga dengan jumlah aset yang ada di Kecamatan Magelang Selatan juga paling besar diantara kecamatan lain di kota Magelang yaitu sebesar 36.510.739.800. (Dinas Perindustrian dan Perdagangan Kota Magelang, 2017)

Selain itu masing-masing kelurahan juga mempunyai sektor industri unggulan. industri tahu sangat berpengarah terhadap penyerapan tenaga kerja dimana jumlah tenaga kerja yang bisa diserap total dari desa campur dan trunan sebanyak 405 orang pada industri tahu yang berada di Keluarah Tidar Selatan. Selain itu industri tahu ini di Kota Magelang adalah industri yang paling banyak jumlahnya, bisa kita lihat jumlah tersebut paling banyak diantara jumlah industri-industri yang lain dimana total jumlahnya yaitu 93 industri. Selain itu industri tahu memiliki investasi yang cukup signifikan bahkan terbesar diantara jumlah investasi industri di seluruh Kota Magelang. Dengan jumlah industri yang banyak dan tenaga kerja yang diserap maka industri tahu ini sangatlah berpengaruh terhadap perekonomian di Kota Magelang. (Dinas Perindustrian dan Perdagangan Kota Magelang, 2017)

Sesuai dengan kondisi yang ada pada sektor industri tersebut maka dapat kita ketahui bahwa industri tahu adalah industri yang mendominasi atau paling banyak di Kota Magelang. Dari data dinas perindustrian dan perdagangan Kota Magelang industri tahu paling banyak terdapat di kelurahan Tidar Selatan yang jumlahnya 106 industri. Kemudian dari kelurahan tersebut desa paling banyak atau sentra industri tahu berada di kampung Trunan.

Pokok permasalahan dalam penelitian ini adalah sebagai berikut.

1. Bagaimana profil usaha industri mikro kecil tahu di Trunan, Kelurahan Tidar Selatan, Kecamatan Magelang Selatan, Kota Magelang?

2. Bagaimana pengaruh modal usaha terhadap tingkat pendapatan industri mikro kecil tahu di Trunan, Kelurahan Tidar Selatan, Kecamatan Magelang Selatan Kota Magelang?

3. Bagaimana pengaruh jumlah tenaga kerja terhadap tingkat pendapatan industri mikro kecil tahu di Trunan, Kelurahan Tidar Selatan, Kecamatan Magelang Selatan Kota Magelang ? 
4. Bagaimana pengaruh pengalaman kerja terhadap tingkat pendapatan industri mikro kecil tahu di Trunan, Kelurahan Tidar Selatan, Kecamatan Magelang Selatan, Kota Magelang ?

5. Bagaimana pengaruh jam kerja terhadap tingkat pendapatan industri mikro kecil tahu di Trunan, Kelurahan Tidar Selatan, Kecamatan Magelang Selatan, Kota Magelang ?

Kemudian tujuan dari penelitian ini :

1. Untuk mengetahui profil usaha industri mikro kecil tahu di Trunan, Kelurahan Tidar Selatan, Kecamatan Magelang Selatan, Kota Magelang.

2. Untuk mengetahui apakah modal usaha berpengaruh terhadap pendapatan usaha industri mikro kecil tahu di Trunan, Kelurahan Tidar Selatan, Kecamatan Magelang Selatan, Kota Magelang.

3. Untuk mengetahui apakah jumlah tenaga kerja berpengaruh terhadap pendapatan usaha industri mikro kecil tahu di Trunan, Kelurahan Tidar Selatan, Kecamatan Magelang Selatan, Kota Magelang.

4. Untuk mengetahui apakah pengalaman kerja berpengaruh terhadap pendapatan usaha industri mikro kecil tahu di Trunan, Kelurahan Tidar Selatan, Kecamatan Magelang Selatan, Kota Magelang.

5. Untuk mengetahui apakah jam kerja berpengaruh terhadap pendapatan usaha industri mikro kecil tahu di Trunan, Kelurahan Tidar Selatan, Kecamatan Magelang Selatan, Kota Magelang

\section{TINJAUAN PUSTAKA}

\section{Analisis Pendapatan Usaha}

Analisis Pendapatan adalah suatu hasil yang di dapatkan oleh seseorang setelah melakukan pekerjaan walaupun hasil yang dicapainya masih rendah ataupun sudah cukup tinggi yang nantinya digunakan untuk mencukupi suatu kebutuhan ataupun mengkonsumsi suatu barang dan jasa.

Upaya dalam meninjau Analisis Peningkatan Produksi dan pendapatan didalam kegiatan Industri maka dapat dijelaskan "pada faktor pertumbuhan ekonomi yang mana tergatung pada modal, tenaga kerja dan teknologi, sedangkan komponen pertumbuhan ekonomi dari semua bangsa di dunia yaitu:

1. Akumulasi modal.

2. Pertumbuhan Penduduk.

3. Kemajuan Teknologi.

Akumulasi modal (Capital accumulation) terjadi apa bila sebagian pendapatan ditabungan dan investasi kembali dengan tujuan memperbesar output dan pendapatan kemudian hari. Pertumbuhan penduduk dan pertumbuhan angkatan kerja dianggap sebagai salah satu faktor positif yang memacu pertumbuhan ekonomi, karena pertumbuhan penduduk yang lebih besar berarti ukuran pasar domestik lebih besar. Kemajuan teknologi adalah ditemukan cara baru atau perbaikan cara lama dalam mengenai pekerjaan tradisional (Amalia 2007, 23-24)

Berdasarkan teori ekonomi pendapatan/penerimaan keuntungan mempunyai arti yang sedikit berbeda dengan pengertian keuntungan dari segi pembukuan, ditinjau dari sudut pandangan perusahaan/pembukuan seperti telah diterangkan di atas, keuntungan adalah perbedaan nilai uang dari hasil penjualan yang diperoleh dengan seluruh biaya yang dikeluarkan. Keuntungan menurut pandangan pembukuan, apabila dikurangi lebih lanjut oleh biaya tesembunyi, akan menghasilkan keuntungan ekonomi atau keuntungan murni (Pure profit). (Sukirno 2011:384) 


\section{Pengertian Usaha dan Industri}

Usaha industri merupakan kumpulan perusahaan-perusahaan yang menghasilkan barang-barang homogen atau barang-barang yang mempunyai sifat saling mengganti yang sangat erat (Teguh 2010: 4)

Menurut Hasibuan dalam Teguh (2010: 4) Industri merupakan kumpulan perusahanperusahaan yang menghasilkan barang-barang homogen, atau barang-barang yang mempunyai sifat saling mengganti yang sangat erat. Namun demikian, dari sisi pembentukan pendapatan secara makro industri diartikan sebagai kegiatan ekonomi yang menciptakan nilai tambah.

Dalam sebuah industri, pasti ditemukan adanya analisis industri yaitu sebuah upaya dalam rangka memanfaatkan peluang berbagai macam bisnis dan mengindentifikasikan berbagai macama cara untuk mendapatkan keuntungan dari bisnis itu yang bersifat jangka panjang. Analisis industri bertujuan untuk meramalkan sejumlah perilaku para pesaing dalam sebuah industri, baik yang bersifat lama maupun baru, serta pengaruh yang ditimbulkan dari sejumlah pembangunan industri dan perkembangan pada industri yang berhubungan (Kuncoro 2007: 167).

\section{Usaha Mikro, Kecil dan Menengah}

Berdasarkan ketentuan Pasal 6 UU Nomor 20 Tahun 2008 tentang Usaha Mikro, Kecil, dan Menengah (UMKM) sebagai berikut :

1. Kriteria Usaha Mikro :

a. Memiliki kekayaan bersih paling banyak Rp. 50 juta Rupiah (tidak termasuk tanah dan tempat usaha).

b. Memiliki hasil penjualan atau pendapatan tahunan paling banyak Rp. 300 juta

2. Kriteria Usaha Kecil

a. Memiliki kekayaan bersih lebih dari Rp. 50 juta Rupiah sampai dengan Rp. 500 juta Rupiah (tidak termasuk tanah dan tempat usaha).

b. Memiliki hasil penjualan tahunan lebih dari Rp. 300 juta Rupiah sampai dengan paling banyak Rp. 2,5 milyar Rupiah.

3. Kriteria Usaha Menangah

a. Memiliki kekayaan bersih lebih dari Rp. 500 juta Rupiah sampai dengan Rp. 10 milyar Rupiah (tidak termasuk tanah dan tempat usaha).

b. Memiliki hasil penjualan tahunan lebih dari Rp. 2,5 milyar Rupiah sampai dengan paling banyak Rp. 50 milyar Rupiah.

\section{Teori Modal Usaha}

Modal adalah segala sesuatu yang dapat digunakan untuk menjalankan suatu usaha perusahaan. Modal juga dapat dari dalam perusahaan atau yang penambahan dari pihak pemilik perusahaan dan juga pemilik lain. Modal juga merupakan segala sesuatu yang diberikan dan dialokasikan dalam suatu usaha.

Dalam setiap perekonomian kegiatan memproduksi memerlukan barang modal. Dalam perekonomian primitif sekalipun, modal diperlukan. Dalam perekonomian modern barang modal diperlukan lagi. Modernisasi perekonomian tidak akan berlaku tanpa modal yang kompleks dan sangat tinggi produktivitasnya (Sukirno $2011: 376$ ).

Modal (capital) sering diartikan secara berbeda. Dalam konteks akuntansi, modal diartikan sebagai kekayaan bersih atau ekuitas pemilik dalam bisnis. Dalam manajemen modal dikaitkan dengan keseluruh aktiva sehingga mencakup ekuitas dan utang bisnis. 
Pengertian ini sering diakibatkan oleh perbedaan tujuan pembahasan, dimana akuntansi lebih terkait dengan masalah adaministrasi dan hukum, sedangkan manajemen dengan masalah efesiensi. Terlepas dari perbedaan tersebut ada dua tipe modal yaitu:

1. Modal adalah modal berasal dari luar usaha yang tertanam di dalam perusahaan untuk jangka waktu tertentu lamanya, contoh seperti pinjaman.

2. Modal sendiri ialah modal yang berasal dari pemilik perusahaan dan yang tertanam di dalam perusahaan untuk waktu yang tidak tertentu lamanya. Modal dapat berasal dari pendapatan usaha (keuntungan) Perusahaan. (Firdaus 2009: 10-16)

\section{Teori Tenaga Kerja}

Lewis mengemukakan dalam Sukrino (2011:197) ialah negara berkembang terdapat tenaga kerja yang lebih, akan tetapi sebaliknya menghadapi masalah kekurangan modal dan keluasan tanah yang belum digunakan sangat terbatas. Dilanjutkan bahwa, kelebihan tenaga kerja tersebut merupakan pengangguran terselubung yang dapat dialihkan dan digunakan sektor lain tanpa mengurangi produksi, dengan demikian dapat kita dilihat bahwa hambatan pembangunan yang terutama adalah kekurangan modal dan kekayaan alam terbatas

Tenaga kerja perlu kita ketahui dimana "dari segi kuantitas, tenaga kerja bukanlah suatu hal yang sulit, untuk mendapatkan tenaga kerja yang baik dan bertanggung jawab, diperlukan proses seleksi agar tenaga kerja memiliki jalur karir sendiri. Dalam proses seleksi tenaga kerja, perlu diperhatikan beberapa faktor, seperti tingkat pendidikan, pengalaman, keterampilah, kondisi fisik, dan jenis kelamin. Pengelolaan tenaga kerja juga perlu diperhatikan dengan jumlah karena." kekurangan tenaga kerja dari segi jumlah akan dapat menghambat proses produksi sesuai dengan yang direncanakan. dilanjutkan bahwa. Sedangkan mutu tenaga kerja yang diperlukan dalam proses produksi sangat penting untuk menjamin agar penempatan tenaga kerja yang direkrut sesuai dengan spesifikasi yang dibutuhkan dalam suatu jenis pekerjaan" (Sa'id dan Intan 2004 : 44).

\section{Teori Pengalaman Kerja}

Pengalaman kerja menentukan keterampilan dalam melaksanakan suatu tugas tertentu, pengalaman kerja dapat berdampak positif atau negatif terhadap kemampuan seseorang (Fadilah, 2008). Pengalaman bekerja merupakan modal utama seseorang untuk terjun dalam bidang tertentu. Perusahaan yang belum begitu besar omset keluaran produksinya, cenderung lebih mempertimbangkan pengalaman kerja daripada pendidikan yang telah diselesaikannya. Tenaga kerja yang berpengalaman dapat langsung menyelesaikan tugas dan pekerjaanya. Mereka hanya memerlukan pelatihan dan petunjuk yang relatif singkat. Sebaliknya, tenaga kerja yang mengandalkan pendidikan dan gelar yang disandangnya, belum tentu mampu mengerjakan tugas dan pekerjaan dengan cepat. Mereka perlu diberikan pelatihan yang memakan waktu dan biaya yang tidak sedikit, karena terkadang teori yang diperoleh dari bangku pendidikan berbeda dengan praktek di lapangan pekerjaan (Sastrohadiwiryo, 2001:163).

\section{Teori Jam Kerja}

Bekerja didefinisikan melakukan suatu kegiatan untuk menghasilkan barang atau jasa dengan tujuan untuk memperoleh pendapatan berupa uang dalam kurun waktu tertentu (Mantra, 2003:225). Jam kerja dapat diartikan sebagai waktu yang dicurahkan untuk bekerja. Jam kerja seluruh pekerjaan adalah jumlah jam kerja yang dilakukan oleh seseorang selama 
seminggu yang lalu . Secara umum dapat diasumsikan bahwa semakin banyak jam kerja yang digunakan berarti pekerjaan yang dilakukan semakin produktif (BPS, 2007:14).

\section{Hasil Penelitian Terdahulu}

Beberapa penelitian terdahulu yang berkaitan dengan penelitian ini telah banyak dilakukan baik penelitian mengenai analisis pendapatan suatu industri baik itu usaha kecil dan menengah maupun industri yang lumayan besar. Nurmedika, Marhawati M, Max Nur Alam (2013) dengan judul "Analisis Pendapatan dan Nilai Tambah Keripik Nangka Pada Industri Rumah tangga Tiara di Kota Palu". Penelitian dilaksanakan pada bulan Juli-Agustus 2012 pada usaha rumah tangga keripik nangka Tiara. Dari penelitian tersebut dapat disimpulkan penerimaan total yang diperoleh industri rumah tangga Tiara selama Bulan Juli Tahun 2012 sebesar Rp. 58.500.000. Setelah dikurangi dengan biaya total didapat pendapatan bersih sebesar Rp. 36.307.614,25. Hal ini berarti agroindustri keripik nangka cukup baik untuk diusahakan, karena memberikan keuntungan yang cukup besar bagi produsen. Sedangkan besarnya nilai tambah keripik nangka yang diperoleh sebesar Rp. 33.169/kg. Hal ini menunjukan bahwa setiap satu kilogram buah nangka segar setelah mengalami proses produksi mampu memberikan nilai tambah sebesar Rp. 33.169.

Ni Kadek Arifin, Made Dwi Setyadhi Mustika (2013) dengan judul "Analisis Pendapatan Pengrajin Perak di Desa Kamasan Kab. Klungkung". Penelitian ini dilakukan di Desa Kamasan Kabupaten Klungkung. Dipilihnya Desa Kamasan sebagai lokasi penelitian Karena di Desa Kamasan terdapat sentra industri kerajinan perak dengan jumlah unit usaha terbanyak yaitu 70 unit usaha dan jumlah tenaga kerja terbanyak yaitu 560 orang. Dengan kesimpulan yaitu : Berdasarkan hasil uji secara serempak menunjukkan bahwa jumlah produk, jam kerja dan pengalaman kerja secara serempak berpengaruh signifikan terhadap pendapatan pengrajin perak di Desa Kamasan Kabupaten Klungkung. Besarnya pengaruh ketiga variabel bebas terhadap pendapatan pengrajin perak di Desa Kamasan Kabupaten Klungkung ditunjukkan dengan nilai Adjusted R Square sebesar 0,567 yang berarti bahwa pendapatan pengrajin perak di Desa Kamasan Kabupaten Klungkung dipengaruhi jumlah produk, jam kerja dan pengalaman kerja sebesar 56,7 persen dan sisanya sebesar 43,3 persen dipengaruhi oleh variabel lain yang tidak dimasukan dalam model penelitian ini. Berdasarkan hasil uji secara parsial menunjukkan jumlah produk dan pengalaman kerja secara parsial berpengaruh positif dan signifikan terhadap pendapatan pengrajin perak di Desa Kamasan Kabupaten Klungkung. Jam kerja tidak berpengaruh secara parsial terhadap pendapatan pengrajin perak di Desa Kamasan Kabupaten Klungkung.

\section{Hipotesis}

Dalam penelitian ini akan dirumuskan hipotesis guna memberikan arah dan pedoman dalam melakukan penelitian. Hipotesis yang digunakan dalam penelitian ini adalah :

1. Modal berpengaruh positif terhadap pendapatan Pengusaha mikro kecil tahu.

2. Tenaga kerja berpengaruh positif terhadap pendapatan Pengusaha mikro kecil tahu.

3. Pengalaman kerja berpengaruh positif terhadap pendapatan Pengusaha mikro kecil tahu.

4. Jam kerja berpengaruh positif terhadap pendapatan Pengusaha mikro kecil tahu. 


\section{METODE PENELITIAN}

Dalam menyusun penelitian ilmiah diperlukan strategi dan langkah-langkah yang benar sesuai dengan tujuan penelitian. Hal ini dimaksudkan agar hasil penelitian dapat dipertanggungjawabkan secara ilmiah. Penelitian ini dilaksanakan dengan menggunakan satu metode. Dalam penelitian ini, penulis menggunakan metode kuantitatif

\section{Waktu dan Tempat Penelitian}

Penelitian dilaksanakan pada bulan Juli - Agustus 2018 di industri tahu yang berlokasi di Kampung Trunan, Kelurahan Tidar Selatan, Kecamatan Magelang Selatan, Kota Magelang .Penentuan lokasi penelitian dilakukan dengan sengaja dengan pertimbangan bahwa di Kampung Trunan ini merupakan sentra industri tahu di Kota Magelang.

\section{Sampel.}

penelitian ini peneliti menggunakan rumus slovin yang mana rumus ini adalah formula untuk menghitung jumlah sampel minimal apabila perilaku dari sebuah populasi tidak diketahui secara pasti. Rumus slovin bisa digunakan dalam penilitian survey dimana jumlah sampel besar sekali, sehingga diperlukan sebuah formula untuk mendapatkan sampel yang sedikit tetapi dapat mewakili keseluruhan populasi.

Rumus slovin

$$
\mathrm{n}=\frac{N}{1+N e^{2}}
$$

$\mathrm{N}$ : adalah populasi/sampel

e : adalah error margin

Jadi rumus ini memberikan kesempatan kepada peniliti untuk menetapkan besar sampel minimal berdasarkan tingkat kesalahan error dimana peneliti menggunakan tingkat error 2,5\%. Dan setelah dihitung dengan rumus tersebut maka didapatkan besar sampel sebanyak 60 industri tahu kemudian oleh peneliti dibulatkan menjadi untuk meneliti semua industri tahu yang berjumlah 62 industri di Trunan.

\section{Sumber Data}

Data yang dikumpulkan dalam penelitian ini terdiri atas dua jenis yaitu:

1. Data Primer, diperoleh melalui wawancara langsung dengan menggunakan kuesioner yang berisikan pertanyaan-pertanyaan secara tertulis pada responden untuk mendapatkan jawaban, tanggapan dan informasi yang diperlukan oleh peneliti.

2. Data Sekunder, diperoleh melalui pencatatan pada instansi atau lembaga terkait misal BPS dan Dinas Perindutrian dengan penelitian ini serta literatur yang menunjang dan memiliki hubungan dengan penelitian ini.

\section{Teknik Pengumpulan Data}

Teknik pengumpulan data digunakan untuk mendapatkan data-data yang akurat, sehingga teknik pengumpulan data dalam sebuah penelitian sangat dibutuhkan. Teknik pengumpulan data adalah salah satu prosedur yang sistematis dan standar untuk memperoleh data yang diperlukan dalam pelaksanaan penelitian (Bungin 2003, h. 188). Adapun beberapa teknik pengumpulan data yang dilakukan dalam penelitian ini, yaitu sebagai berikut:

1. Studi Pustaka (Library Research)

Studi Pustaka (Library Research) yaitu sebuah metode pengumpulan data yang digunakan untuk mengumpulkan data yang diperlukan dalam penelitian dengan cara membuka buku-buku dan literatur-literatur lainnya yang diperlukan (Nazir Moh 2003, h. 48). 


\section{Penelitian Lapangan (Field Research)}

Penelitian Lapangan (Field Research) yaitu sebuah metode pengumpulan yang digunakan untuk mengumpulkan seluruh data penelitian secara langsung dari lapangan penelitian dilakukan. Adapun cara pengumpulan data yang ditempuh melalui penelitian lapangan (field research) yaitu sebagai berikut:

1. Observasi (pengamatan)

2. Wawancara .

3. Kuesoner

\section{Teknik Analisis Data}

\section{Analisis Linier Berganda}

Analisis regresi linier berganda merupakan teknik analisis yang digunakan untuk mengetahui ada tidaknya pengauh variabel bebas yaitu modal (X1), tenaga kerja (X2), pengalaman kerja (X3), dan jam kerja (X4) terhadap variabel terikat yaitu pendapatan industri mikro kecil di Kampung Trunan, Kelurahan Tidar Selatan, Kecamatan Magelang Selatan, Kota Magelang (Y). Adapun bentuk umum persamaan regresi linier berganda menurut (Wirawan, 2002:293) sebagai berikut.

$$
Y=\beta_{0}+\beta_{1} X_{1}+\beta_{2} X_{2}+\beta_{3} X_{3}+\beta_{4} X_{4} e
$$

Keterangan :

$\mathrm{Y}=$ Pendapatan industri mikro kecil tahu di Trunan

$\mathrm{X} 1=$ modal

$\mathrm{X} 2$ = tenaga kerja

$\mathrm{X} 3$ = pengalaman kerja

$\mathrm{X} 4$ = pengaruh jam kerja

$\beta 0=$ Konstanta

$\beta 1, \beta 2, \beta 3=$ Koefisien regresi dari masing-masing variabel bebas $\mathrm{X} 1, \mathrm{X} 2, \mathrm{X} 3, \mathrm{X} 4$

\section{Uji Signifikansi Koefisien Regresi Secara Serempak (Uji-F)}

Uji kelayakan model atau yang lebih populer disebut sebagai uji $\mathrm{F}$ (ada juga yang menyebutnya sebagai uji simultan model) merupakan tahapan awal mengidentifikasi model regresi yang diestimasi layak atau tidak. Uji-F dipergunakan untuk pengujian variabel bebas yaitu modal (X1), tenaga kerja (X2), pengalaman kerja (X3), dan jam kerja (X4) secara serempak berpengaruh terhadap variabel terikat pendapatan industri mikro kecil tahu di Trunan, Kelurahan Tidar Selatan, Kecamatan Magelang Selatan, Kota Magelang (Y).

HO : Berarti variabel bebas tidak memiliki pengaruh dengan variabel bebas.

$\mathrm{Ha}$ : Berarti ada pengaruh secara serentak antara semua variabel bebas terhadap variabel terikat.

Apabila F Hitung > F Tabel maka H0 di tolak Ha diterima, yang berarti bahwa variabel bebas $(\mathrm{X} 1, \mathrm{X} 2, \mathrm{X} 3$, dan $\mathrm{X} 4)$ secara serentak signifikan terhadap variabel terikat (Y)

Apabila F Hitung < F Tabel maka H0 di terima Ha ditolak, yang berarti bahwa variabel bebas $(\mathrm{X} 1, \mathrm{X} 2, \mathrm{X} 3$, dan $\mathrm{X} 4)$ secara serentak tidak signifikan terhadap variabel terikat $(\mathrm{Y})$. (Mahulete,2016).

\section{Uji Signifikansi Koefisien Regresi Secara Parsial (Uji-t)}

Uji $\mathrm{T}$ dalam regresi linier berganda dimaksudkan untuk menguji apakah parameter (koefisien regresi dan konstanta) yang diduga untuk mengestimasi persamaan/model regresi linier berganda sudah merupakan parameter yang tepat atau belum. Maksudnya adalah parameter tersebut mampu menjelaskan perilaku variabel bebas dalam mempengaruhi 
variabel terikatnya. Parameter yang diestimasi dalam regresi linier meliputi intersep (konstanta) dan slope (koefisien dalam persamaan linier). Pada bagian ini, uji t difokuskan pada parameter slope (koefisien regresi) saja. Jadi uji t yang dimaksud adalah uji koefisien regresi. Hasil pengujian dapat dilihat pada tabel Coefficients.

Uji-t dilakukan untuk melihat pengaruh variabel bebas yaitu modal (X1), tenaga kerja (X2), pengalaman kerja (X3), dan jam kerja (X4) secara parsial terhadap variabel terikat yaitu pendapatan pendapatan industri mikro kecil tahu di Trunan, Kelurahan Tidar Selatan, Kecamatan Magelang Selatan, Kota Magelang (Y), dengan asumsi variabel bebas lainnya dianggap konstan.

Untuk mengetahui hipotesis mana yang diterima atau ditolak, maka harus dilakukan perbandingan antara nilai $t$ hitung dengan $t$ tabel yang mana apabila $t$ hitung $>t$ tabel maka H0 ditolak Ha diterima yang berarti variabel bebas (X1,X2,X3, danX4) secara parsial berpengaruh positif terhadap variabel terikat (Y) adalah signifikan. Begitupun sebaliknya jika $\mathrm{t}$ hitung < t tabel maka H0 diterima dab Ha ditolak yang berarti variabel bebas $(\mathrm{X} 1, \mathrm{X} 2, \mathrm{X} 3$, dan $\mathrm{X} 4)$ secara parsial berpengaruh positif terhadap variabel terikat (Y) adalah tidak signifikan.

\section{Koefisien Determinasi $\left(\mathbf{R}^{2}\right)$}

Koefisien determinasi $\left(\mathrm{R}^{2}\right)$ pada intinya mengukur seberapa jauh kemampuan model dalam menerangkan variasi variabel dependen. Nilai koefisien determinasi adalah di antara nol dan satu. Nilai $\mathrm{R}^{2}$ yang kecil berarti kemampuan variabel-variabel independen dalam menjelaskan variasi variabel dependen amat terbatas. Nilai yang mendekati satu berarti variabel-variabel independen memberikan hampir semua informasi yang dibutuhkan untuk memprediksi variasi variabel dependen.

Besarnya nilai $\mathrm{R}^{2}$ berada di antara 0 (nol) dan 1 (satu) yaitu $0<\mathrm{R}^{2}<1$ semakin 1 (satu), maka model tersebut baik dan pengaruh antara variabel terikat $\mathrm{Y}$ semakin kuat. (Mahulete,2016)

\section{5) Uji Asumsi Klasik}

\section{Uji Heteroskedastisitas}

Uji heteroskedastisitas bertujuan untuk menguji apakah dalam model regresi terjadi ketidaksamaan varians dari residual satu pengamatan ke pengamatan yang lain. Uji ini merupakan salah satu uji asumsi klasik yang harus dilakukan pada regresi linear. Apabila asumsi heteroskedastisitas tidak terpenihi, maka model regresi dinyatakan tidak valid sebagai alat peramalan.

Ada beberapa metode pengujian uang bisa digunakan untuk meneliti uji heteroskedastisitas tapi peneliti akan mengunakan metode grafik scatterplot.

\section{Uji Autokorelasi}

Uji autokorelasi digunakan untuk digunakan untuk mengetahui ada atau tidaknya penyimpangan korelasi yang terjadi antara residual pada pengamatan dengan pengamatan lain pada model regresi. Prasyarat yang harus terpenuhi adalah tidak adanya autokorelasi dalam model regresi.

\section{HASIL DAN PEMBAHASAN} Analisis Linier Berganda

Analisis ini digunakan untuk memperoleh gambaran yang menyeluruh mengenai hubungan antar variable independen terhadap dependen. Persamaan regresi ini dapat dilihat dari table hasil uji koefisien berdasarkan output SPPS IBM versi 17 terhadap variable 
independennya keterlibatan antara modal, jumlah tenaga kerja, jumlah produksi, pengalaman kerja, dan jam kerja.

Tabel 1

Hasil Analisis Regresi

\begin{tabular}{|l|r|r|r|l|l|}
\hline \multirow{2}{*}{ Model } & \multicolumn{2}{|c|}{ Unstrandardized Coefficients } & $\begin{array}{c}\text { Unstrandardize } \\
\text { d Coefficients }\end{array}$ & \multirow{2}{*}{ T } & \multirow{2}{*}{ Sig } \\
\cline { 2 - 5 } & \multicolumn{1}{|c|}{ B } & Std. Error & \multicolumn{1}{c|}{ Beta } & & \\
\hline (Constant) & -1530879.005 & 1518670.284 & & -1.008 & .318 \\
\hline Modal Usaha & .084 & .025 & .231 & 3.393 & .001 \\
\hline Tenaga Kerja & 2470861.828 & 228589.229 & .665 & 10.809 & .000 \\
\hline Pengamalan Kerja & 72660.934 & 33601.606 & .145 & 2.162 & .035 \\
\hline Jam Kerja & -148611.690 & 136585.162 & -.043 & -1.088 & .281 \\
\hline
\end{tabular}

Dari hasil regresi seperti tabel diatas, dapat disimpulkan bahwa dari empat variabel bebas yang digunakan, terdapat tiga variabel bebas yaitu modal usaha, tenaga kerja, dan pengalaman kerja yang mempunyai tingkat signifikan dibawah $\alpha 5$ persen. Sedangkan variabel jam kerja mempunyai tingkat signifikan diatas $\alpha 5$ persen. Hal ini menunjukkan bahwa variabel usaha, tenaga kerja, dan pengalaman kerja mempunyai pengaruh yang signifikan terhadap variabel terikat yaitu pendapatan.

\section{Uji Simultan (Uji F)}

Uji $\mathrm{F}$ ini biasa digunakan untuk mengetahui pengaruh variabel independen secara signifikan terhadap variabel dependen. Dengan menggunakan $\alpha=5 \% \mathrm{df}=\mathrm{k}-1 / \mathrm{n}-\mathrm{k}=5-1 /$ $62-5=4$ dan 57 maka diperoleh hasil F-tabel adalah 2.53 diperoleh hasil sebagai berikut:

Tabel 2

Hasil Pengujian Uji Simultan (Uji F)

\begin{tabular}{|c|c|}
\hline F (Hitung) & Sig. \\
\hline 321.619 & $0.000^{\mathrm{a}}$ \\
\hline F-tabel & 2.53 \\
\hline
\end{tabular}

Dari hasil regresi yang ditunjukkan pada tabel diatas, dapat diketahui bahwa nilai $\mathrm{F}$ hitung adalah sebesar 321.619 dengan tingkat signifikansi 0.000. untuk nilai F-tabel pada signifikansi (0.05) derajat kebebasan pembilang adalah 2.53. Oleh karena F-hitung > F-tabel $(321.619>2.53)$ dan signifikansi $<\alpha(0.000<0.05)$ maka $\mathrm{H}_{0}$ ditolak dan Ha diterima. Dari pengaruh variabel modal usaha (X1), tenaga kerja (X2), pengalaman kerja (X3), dan jam kerja (X4), terhadap pendapatan pengusaha industri tahu di Trunan, maka diperoleh nilai signifikan $0.000<0.05$, hal ini menunjukkan bahwa empat variabel bebas secara simultan/ bersama-sama berpengaruh signifikan terhadap variabel terikat.

\section{Uji T}

Pada penelitian ini faktor yang berpengaruh terhadap pendapatan pengusaha mikro kecil tahu yang dianalisis dengan regresi linier berganda dengan jumlah sampel 62 industri yang berada di Trunan. Menentukan taraf signifikansi menggunakan $\alpha=5 \% \mathrm{~T}$ tabel dapat diketahui $\mathrm{df}=\mathrm{n}-\mathrm{k}=62-6=56$, taraf signifikansi 0.05 yaitu 1.672 untuk satu sisi. 
H0 : b1 $\leq 0$ tidak ada pengaruh positif variabel independen terhadap variabel dependen.

Ha : b1 > 0 ada pengaruh positif variabel independen terhadap variabel dependen.

\section{Tabel 3}

Uji T

\begin{tabular}{|l|l|l|l|l|}
\hline Model & T-hitung & T-tabel & Sig & Kesimpulan \\
\hline Modal usaha & 3.393 & 1.672 & .001 & Signifikan \\
\hline Tenaga kerja & 10.809 & 1.672 & .000 & Signifikan \\
\hline Pengalaman kerja & 2.162 & 1.672 & .035 & Signifikan \\
\hline Jam kerja & -1.088 & 1.672 & .281 & Tidak signifikan \\
\hline
\end{tabular}

\section{Pengujian Hipotesis (X1= Modal usaha)}

Berdasarkan tabel diatas dapat diketahui bahwa nilai t-hitung variabel Modal usaha sebesar 3.393 dengan angka probabilitas signifikansi .001. Hal tersebut menunjukan bahwa thitung lebih besar dari pada t-tabel $(3.393>1.672)$ dan angka probabilitas signifikansi variabel modal usaha lebih besar dari $0.05(0.01>0.05)$. Hal inilah dapat disimpulkan bahwa Ho ditolak dan menerima Ha dan modal usaha berpengaruh signifikan terhadap pendapatan industri mikro kecil tahu (+).

\section{Pengujian Hipotesis (X2= Tenaga Kerja)}

Berdasarkan tabel atas dapat diketahui bahwa nilai t-hitung adalah 10.809 dengan angka probabilitas signifikansi .000. Hal tersebut menunjukkan bahwa t-hitung tenaga kerja lebih besar dari t-tabel $(10.809>1.672)$ dimana angka probabilitas signifikansi variabel tenaga kerja lebih kecil dari $0.05(0.000<0.05)$. Hal inilah dapat disimpulkan bahwa Ho ditolak dan menerima Ha dan tenaga kerja berpengaruh signifikan terhadap pendapatan industri mikro kecil tahu (+).

\section{Pengujian Hipotesis (X3= Pengalaman Kerja)}

Berdasarkan tabel diatas dapat diketahui bahwa nilai t-hitung variabel pengalaman kerja sebesar 2.162 dengan angka probabilitas signifikansi .035. Hal tersebut menunjukan bahwa thitung lebih kecil dari pada t-tabel $(2.162>1.672)$, dimana angka probabilitas signifikansi variabel pengalaman kerja lebih besar dari $0.05(0.035<0.05)$. Hasil ini dapat disimpulkan bahwa Ho ditolak dan menerima Ha dan pengalaman kerja berpengaruh signifikan terhadap pendapatan industri mikro kecil tahu (+).

\section{Pengujian Hipotesis (X4= Jam Kerja)}

Berdasarkan tabel diatas dapat diketahui bahwa nilai t-hitung variabel jam kerja sebesar 1.088 dengan angka probabilitas signifikansi .281. Hal tersebut menunjukan bahwa t-hitung lebih kecil dari pada t-tabel $(-1.088>1.697)$, dimana angka probabilitas signifikansi variabel jam kerja lebih besar dari $0.05(0.281>0.05)$.. Hasil ini dapat disimpulkan bahwa Ho diterima dan menolak Ha dan jam kerja tidak berpengaruh secara signifikan terhadap pendapatan industri mikro kecil tahu. 


\section{Uji Koefisien Determinasi}

Tabel 4

Hasil Perhitungan Koefisien Determinasi $\left(\mathbf{R}^{2}\right)$

\begin{tabular}{|l|l|l|}
\hline Model & R square & Adjusted R Square \\
\hline 1 & .958 & .955 \\
\hline
\end{tabular}

Berdasarkan Tabel diatas "Hasil Perhitungan Koefisien Determinasi" dapat disimpulkan bahwa variabel modal (X1), tenaga kerja (X2), jumlah produksi (X3), pengalaman kerja (X4), dan jam kerja (X5), berpengaruh sebesar 0.958 atau 95,8\% terhadap pendapatan pengusaha tahu sedangkan $4.2 \%$ dipengaruhi variabel lain yang tidak ada dalam model penelitian ini.

\section{Uji Asumsi Klasik}

Analisis uji prasyarat dalam penelitian ini yaitu mengunakan uji asumsi klasik sebagai salah satu syarat dalam mengunakan analisis regresi.

\section{Uji Heteroskedastisitas}

Pada uji heteroskedastisitas menggunakan metode grafik scatterplot dapat disajikan pada gambar 4.2 berikut :

\section{Gambar 1}

Hasil Uji Heteroskedastisitas

Scatterplot

\section{Dependent Variable: pendapatan}

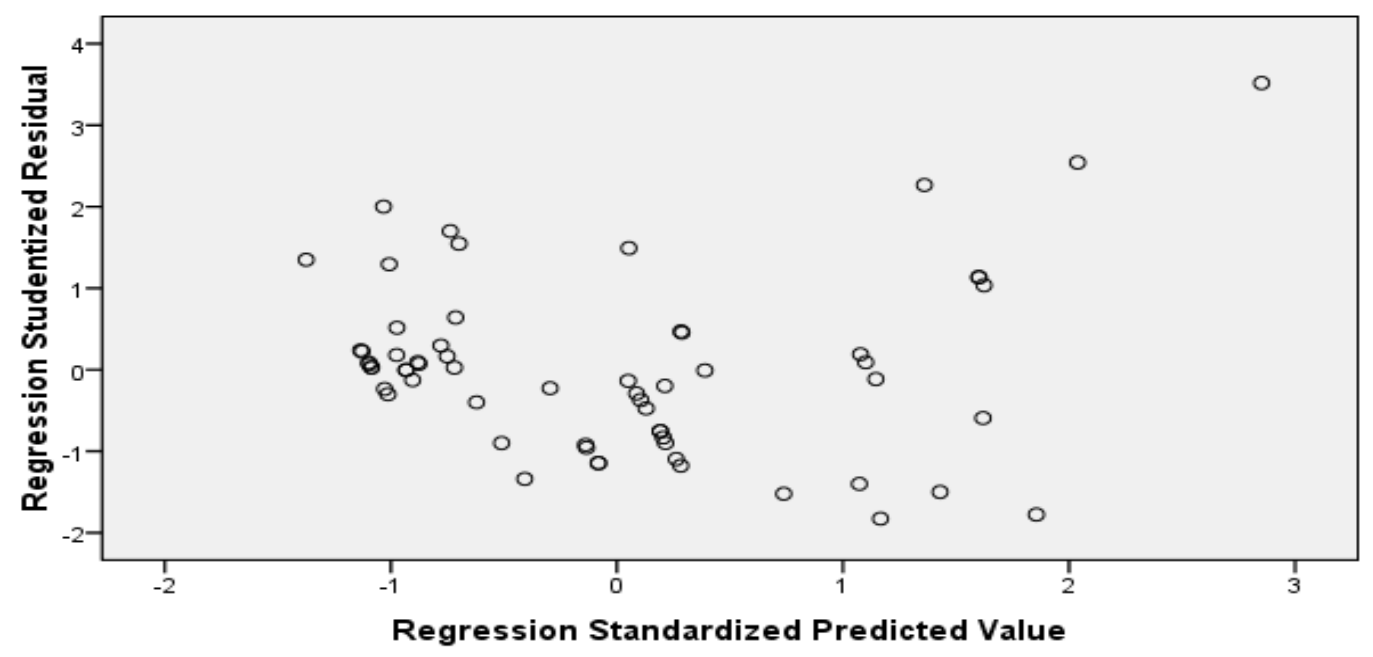

Berdasarkan hasil pengujian heteroskedastisitas diketahui bahwa titik-titik yang terbentuk pada grafik scatterplot tidak membentuk pola yang jelas serta tersebar di atas dan di bawah angka 0 pada sumbu Y. Dari grafik diatas dapat diambil kesimpulan bahwa model regresi yang digunakan bebas heteroskedastisitas atau tidak ada heteroskedastisitas. 


\section{Uji Autokorelasi}

Adalah keadaan dimana faktor-faktor pengganggu yang satu dengan yang lain saling berhubungan, pengujian terhadap gejala autokorelasi dapat dilakukan dengan uji DurbinWatson (DW) :

\section{Tabel 5}

Hasil Pengujian Autokorelasi

\begin{tabular}{|c|c|c|}
\hline DW & dL & dU \\
\hline 1.879 & 1.4026 & 1.7671 \\
\hline
\end{tabular}

Dari tabel diatas dapat dilihat bahwa hasil uji regresi diperoleh nilai Durbin Watson 1.879. Dengan menggunakan derajat keyakinan 5\% dengan jumlah sampel sebanyak 62 , dan 5 variabel penjelas, maka diperoleh nilai $\mathrm{dL}=1.4026, \mathrm{dU}=1.7671,4-\mathrm{dU}=2.2329,4-\mathrm{dL}=$ 2.5974. Dari hal tersebut bisa dipastikan nilai d lebih besar dari pada nilai dU (1.879 > 1.7671) maka tidak terdapat autokorelasi positif. Kemudian nilai (4-d) yaitu 2.121 lebih besar dari pada dU maka tidak terdapat autokorelasi negatif. dari hal tersebut dapat disimpulkan bahwa dalam analisis regresi tidak terdapat sama sekali autokorelasi.

\section{KESIMPULAN \\ Kesimpulan}

Berdasarkan pembahasan pada bab sebelumnya, dapat ditarik beberapa kesimpulan mengenai pengaruh modal, tenaga kerja, jumlah produksi, pengalaman kerja, dan jam kerja terhadap pendapatan industri meubel di Trunan Kelurahan Tidar Selatan Kecamatan Magelang Selatan Kota Magelang. Dari model persamaan regresi dapat dijelaskan bahwa:

1. Variabel bebas modal (X1) berpengaruh secara signifikan terhadap pendapatan pengusaha tahu di Trunan Kelurahan Tidar Selatan Kecamatan Magelang Selatan Kota Magelang. Artinya Modal akan mempengaruhi skala usaha yang pada akhirnya akan mempengaruhi besar atau kecilnya jumlah produksi suatu usaha industri tahu. Besar atau kecilnya jumlah produksi akan mempengaruhi pendapatan pengusaha tahu, yang mana pengusaha yang mempunyai modal yang besar akan mendapatkan hasil produksi yang banyak sehingga memperoleh penghasilan yang banyak pula.

2. Variabel bebas tenaga kerja (X2) menyatakan bahwa tenaga kerja berpengaruh signifikan dan bernilai positif terhadap pendapatan pengusaha industri mikro kecil tahu. Artinya maka semakin bertambahnya tenaga kerja yang digunakan akan membuat semakin cepatnya proses produksi dan bisa juga menambah hasil produksi dan akan menambah juga pendapatan para pengusaha tahu di Trunan Kelurahan Tidar Selatan Kecamatan Magelang Selatan Kota Magelang.

3. Variabel bebas pengalaman kerja (X3) menyatakan bahwa pengalaman kerja berpengaruh signifikan dan bernilai posotif terhadap pendapatan pengusaha industri tahu. Artinya semakin lama pengalaman kerja atau semakin lama pengusaha tahu menjalankan usahanya maka akan mempengaruhi pendapatan pengusaha tahu di Trunan Kelurahan Tidar Selatan Kecamatan Magelang Selatan Kota Magelang.

4. Variabel bebas jam kerja (X4) tidak berpengaruh secara signifikan dan bernilai negatif terhadap pendapatan pengusaha tahu di Trunan Kelurahan Tidar Selatan Kecamatan Magelang Selatan Kota Magelang. Artinya walaupun jam kerja lebih ditingkatkan dari waktu normal maka tidak akan mempunyai pengaruh yang positif terhadap pendapatan pengusaha tahu. Selain itu karena faktor proses produksi yang masih tradisional yang membuat proses satu ke proses selanjutnya tidak efisian dan memerlukan waktu lama. 


\section{Saran}

Berdasarkan hasil analisis dan pembahasan pada bab sebelumnya, dikemukakan beberapa saran sebagai berikut:

1. Untuk meningkatkan produksi dan pendapatan industri mikro kecil tahu maka perlu ditunjang oleh adanya dukungan dari berbagai faktor-faktor produksi seperti modal, jumlah tenaga kerja yang terampil dan pengalaman kerja. Karena pengalaman usaha juga berpengaruh terhadap pendapatan pengusaha tahu sendiri. Selain itu semakin lama pengusaha menjalankan usahanya maka produk-produk yang dihasilkan para pengusaha tersebut akan semakin dikenal oleh para konsumen dan para pendistribusi tahu yang akan menjadi pelanggan tentunya.

2. Hendaknya pihak pengusaha lebih memperhatikan efisiensi dalam mengatur jam operasional produksi tahu seperti mengatur jam-jam kapan melakukan proses perendaman, kemudian penggilingan, pencetakan, atau proses lainnya agar hasil produksi berbanding seimbang dengan jam operasional kerja yang dilakukan.

\section{DAFTAR PUSTAKA}

Ahmad, Firdaus. 2009. Akuntasi Biaya. Edisi 2, Salemba 4. Jakarta

Alam, N., dkk. 2013. Analisis Pendapatan dan Nilai Tambah Kripik Nangka Pada Industri Tiara di Kota Palu. Jurnal Agrotekbis.

Arifin. N.K., Mustika, M. 2013. Analisis Pendapatan Pengerajin Perak di desa Kamasan Kabupaten Klungkung. E Jurnal Ekonomi Pembangunan. Vol. 2 No. 6. Hal 277-313.

Arsyad, Lincolin. 2010. Ekonomi Pembangunan. Yogyakarta: UPP STIM YKPN.

Bagoes, Mantra. 2003. Demografi Umum. Yogyakarta. Pustaka Pelajar.

BPS Magelang Dalam Angka 2012-2016

Dinas Perindustrian dan Perdagangan Kota Magelang . 2017. Hasil pendapatan UMKM Kota Magelang tahun 2017.

Fadilah. 2006. Sukses Beternak Ayam. Agromedia Pustaka. Jakarta

Gumbira, Sa'id, A. Haritz Intan .2004. Manajemen Agribisnis. Jakarta : Ghalia Indonesia.

Lia, Amalia. 2007. Ekonomi Pembangunan. Edisi I. Graha Ilmu. Yogyakarta.

Muhamad, Teguh., 2010. Ekonomi Industri, Cetakan Ke-1, PT Raja Grafindo Persada, Jakarta.

Kuncoro, Mudrajad. 2007. Ekonomika Industri Indonesia Menuju Negara Industri Baru 2030. Yogyakarta: C.V Andi.

Sastrohadiwiryo, Siswanto. 2001. Manajemen Tenaga Kerja Indonesia..

Sukirno, Sadono. 2011. Mikro Ekonomi Edisi Ketiga, PT. Raja Grafindo Persada. Jakarta.. Undang-Undang No.5 Tahun 1984 Tentang Perindustrian

Undang-Undang No.20 Tahun 2008 Tentang Usaha Mikro, Kecil, dan Menengah 